In deze rubriek komen onderzoekers aan het woord over participerende observatie. Zij doen verslag van hun eigen ervaringen en inzichten en volgen daarbij het spoor dat antropoloog Bronislaw Malinowski begin vorige eeuw uitzette. Geïnteresseerden kunnen contact opnemen met Frank van Gemert:f.vangemert@rechten.vu.nl.

\title{
Etnografisch onderzoek onder collega's; voortdurende spanning tussen betrokkenheid en distantie
}

\author{
Yvonne Jansen
}

Dit artikel gaat over de spanning tussen 'betrokkenheid' en 'distantie' verbonden aan participerende observatie binnen een onderzoeksproject dat wordt uitgevoerd door collega-onderzoekers.

Steeds vaker wordt kwalitatief onderzoek - in al haar vormen - toegepast binnen kwantitatief georiënteerd medisch interventieonderzoek. Vaak zijn de medische interventies, die worden bestudeerd, complex van aard, omdat ze bestaan uit een combinatie van verschillende effectief bevonden kleinere interventies. Ze worden veelal uitgevoerd in vergelijkbare, maar verschillende medische settings. Vanwege de complexiteit van de medische interventies en de inherente moeilijkheid voor interventieonderzoekers om het 'effect' van deze interventies eenduidig te bepalen wordt kwalitatief onderzoek steeds vaker toegepast. Zo verkrijgt men inzicht in alle werkprocessen, sociale interacties en veranderingen, die de werking en de uitkomsten van complexe interventies uiteindelijk bepalen.

Het onderzoeksproject waar ik als antropoloog in 2003 bij betrokken raakte, is hier een voorbeeld van. Het betrof een grote effectstudie naar de implementatie van multidisciplinaire zorgteams in vijf verschillende huisartsenpraktijken in achterstandswijken van Rotterdam en Den Haag voor de preventie van hart- en vaatziekten. Door middel van een gerandomiseerd experiment (dat wil zeggen vergelijking van een experimentgroep met controlegroepen) werd geëvalueerd of multidisciplinaire zorg een verlagend effect had op het risico van hart- en vaatziekten van de patiënten die het onderzoek omvatte. Op het moment dat ik bij het project betrokken raakte, was de interventie inmiddels in vier van de vijf praktijken gaande en gaven de eerste tussentijdse resultaten aan dat multidisciplinaire zorg nauwelijks effect sorteerde. Aan mij de taak om door middel van etnografisch onderzoek in de huisartsenpraktijken uit te vinden waarom dat zo was. Mijn achtergrond ligt in het wetenschap- en techniekonderzoek. Het wetenschap- en techniekonderzoek is een interdisciplinair onderzoeksgebied, dat het onderstaan, de dynamiek en de consequenties van wetenschap en techniek in de samenleving bestudeert. In dit project zou sprake kunnen zijn van een dynamisch proces waarbij 'onderzoek' en 'huisartsenpraktijk van alledag' op elkaar inwerken en daarmee consequenties hebben voor de uitkomsten van de effectstudie, zo redeneerde ik. De opzet van de effect- 
studie door middel van een gerandomiseerd experiment bepaalde weliswaar hoe de interventie uitgevoerd zou moeten worden, maar de omstandigheden in de huisartsenpraktijken bepaalden hoe de interventie daadwerkelijk uitgevoerd zou kunnen worden en haar vorm kreeg. Het was voor mij dan ook een logische keuze om niet alleen te bestuderen hoe de interventie in de huisartsenpraktijken werd uitgevoerd, maar ook te kijken naar hoe mijn epidemiologisch geschoolde collega-onderzoekers de effectstudie uitvoerden. Hoewel je zou kunnen denken dat etnografisch onderzoek onder collega's het voordeel heeft van een 'makkelijke toegang tot het veld', bleek het eerder een belemmering. Het onderzoek kende een voortdurende spanning tussen betrokkenheid en distantie.

\section{Een voordeel blijkt een nadeel}

Ik kreeg een werkplek op dezelfde kamer als de onderzoekers, wat een zeer goede gelegenheid bood voor het verzamelen van data. 'Je krijgt veel informatie zonder dat je daar veel voor hoeft te doen' (fieldnote). Het in dezelfde ruimte werken als mijn collega's gaf me de mogelijkheid van dichtbij te observeren hoe de effectstudie werd uitgevoerd, met welke dilemma's mijn collega's werden geconfronteerd en welke praktische beslissingen daarbij werden genomen. Hoe ideaal de situatie ook mag lijken, hij schept ook bepaalde verwachtingen. Ik deed toch mijn etnografisch onderzoek ten behoeve van het project? Mijn opdracht was toch juist in de huisartsenpraktijken te observeren waarom de interventie geen effect sorteerde? Dan kon ik in het project ook wel allerhande praktische klussen doen. Dat gaf me de gelegenheid om bekend te raken met de effectstudie en de interventie en zo kon ik toegang tot mijn 'onderzoeksveld' krijgen. Maar hoe betrokken moet je als onderzoeker zijn, of hoeveel afstand moet je bewaren tot je onderzoeksobject? In mijn fieldnotes heb ik hierop gereflecteerd: 'Ik begrijp dat zij hun onderzoeksbelangen hebben die voor mij misschien ook wel van belang zijn, maar we hebben toch andere einddoelen? Op dit moment ben ik tot op zekere hoogte afhankelijk van hen vanwege de contacten die zij al hebben, wellicht dat dit op termijn zal veranderen' (fieldnote).

Ik startte dan ook met het assisteren van de onderzoekers bij het uitnodigen van geselecteerde patiënten voor de interventie. Volgens de voorschriften van de medisch-ethische commissie, die het onderzoek had goedgekeurd, werden mensen met een verhoogde kans op hart- en vaatziekten door mijn collega-onderzoekers uit de patiëntpopulatie van de praktijken geselecteerd en zij werden door middel van een brief uitgenodigd om deel te nemen aan het onderzoek. Alvorens de brieven aan de patiënten verstuurd konden worden, dienden de betrokken huisartsen de uitnodigingsbrieven te ondertekenen. Als onderdeel van de procedure moest iemand van het onderzoeksteam - in dit geval ik daarvoor de brieven bij de betreffende huisartsen brengen ter ondertekening. Hoewel mijn collega-onderzoekers blij waren met mijn hulp bij het uitnodigen van patiënten voor het project, stuitte mijn betrokkenheid toch op weerstand. Hoe ging ik mezelf dan introduceren bij de huisartsen als ik hen ging vragen de uitnodigingsbrieven te ondertekenen? En wat ging ik hen vertellen over mijn positie binnen het onderzoeksproject? De hoofdonderzoekster wilde liever niet dat ik bij de huisartsen langsging. '(...) omdat mijn positie bij hen nog onbekend was, kon mijn bezoek aan de huisartsen een bom leggen 
onder de relaties die zij met hen had opgebouwd' (fieldnote). Hoe legitiem haar terughoudendheid ook was, ik zag mijn bezoek aan de huisartsen in het project niet als ondermijnend, maar als een goede gelegenheid ook toegang tot de huisartsenpraktijken te krijgen. Maar hoe kreeg ik nu dan toegang? Als antropoloog was ik toch juist getraind om te kunnen omgaan met voor anderen politiek gevoelige situaties? Ik kon toch toegang krijgen tot het veld, en daarbij de juiste distantie betrachten om mijn collega's relaties niet te schaden? Het was duidelijk: 'ik stapte in het onderzoeksdomein van mijn collega's' (fieldnote). Dat maakte hen alert op de invloed of zelfs schade die dat kon hebben op de relaties die zij hadden opgebouwd met de huisartsenpraktijken. Dat kon het project voor hen bemoeilijken. Ik besloot daarom op dat moment niet zelf naar de huisartsen te gaan, maar later in mijn onderzoek. Het was voor mijn onderzoek belangrijker om toegang te krijgen tot mijn collega-onderzoekers.

\section{Door betrokkenheid en participatie krijg je toegang}

Etnografisch onderzoek doen ten behoeve van het project betekende niet alleen dat ik van mijn collega-onderzoekers afhankelijk was voor de toegang tot de verschillende velden in mijn onderzoek (huisartsenpraktijken en onderzoekssetting), het betekende ook dat er verwacht werd dat ik actief participeerde in het project. Elke twee à drie weken werd er een onderzoeksoverleg gehouden waarin de voortgang van de effectstudie werd besproken. Ook van mij werd verwacht dat ik regelmatig mijn observatieresultaten presenteerde. Goed, mijn etnografisch onderzoek was tenslotte ook onderdeel van het project, maar '(...) door te vertellen over mijn onderzoek beïnvloedde ik dan niet mijn "object van onderzoek"?' (fieldnote). Waar trek je in zulke situaties de grens: wat vertel je collega's wel en wat vertel je hen niet en houd je voor jezelf? Ik kon dit dilemma niet oplossen, maar ik besloot de knoop door te hakken en toch aan de bijeenkomsten deel te nemen. Deze bijeenkomsten waren waardevolle gelegenheden voor mijn dataverzameling, omdat ik juist tijdens deze bijeenkomsten informatie kon verzamelen over hoe de onderzoekers de effectstudie uitvoerden en hoe ze daarbij omgingen met de (methodologische) dilemma's die ze tegenkwamen. Ik besloot daarom mijn observatieresultaten uit de huisartsenpraktijken te presenteren tijdens de onderzoeksoverleggen. Onderdeel zijn van een project betekende immers ook betrokkenheid van mijn kant. Wilde ik informatie ontvangen, dan moest ik ook teruggeven.

Tijdens deze onderzoeksbijeenkomsten werden de verschillen in visies op 'goed' onderzoek tussen mij en mijn collega-onderzoekers steeds duidelijker. Bijvoorbeeld voor mijn etnografisch onderzoek was het belangrijk dat ik kon achterhalen hoe mijn collegaonderzoekers de effectstudie uitvoerden. Voor mijn collega's daarentegen, was het van belang te weten hoe in de huisartsenpraktijken de interventie werd uitgevoerd om het effect van de interventie te bepalen. Mijn observatieresultaten werden een terugkomend punt op de agenda, maar vooral ook een voortdurend punt van discussie. Hoe zorgde ik ervoor dat mijn uitwerkingen van de observaties accuraat waren als ik geen volledige observatie-aantekeningen kon maken tijdens mijn aanwezigheid in de huisartsenpraktijken? En hoe kon ik heel breed de uitvoering van de interventie observeren, zonder naar specifieke kenmerken te kijken? Hoe legitiem kritisch de vragen ook waren die 
mijn collega's stelden, ik moest hen er steeds van proberen te overtuigen dat ook etnografisch onderzoek methodologisch 'goed' onderzoek is en valide en betrouwbare data levert. Achteraf bezien, denk ik dat deze discussies wellicht exemplarisch zijn voor het aloude debat over kwantitatieve en kwalitatieve onderzoeksstromingen.

\section{...maar betrokkenheid en participatie slaan om in distantie}

Naarmate het project vorderde, werden de onderlinge verhoudingen op scherp gezet, en veranderde een 'makkelijke toegang tot het veld' in een groeiende distantie. Tijdens een van de onderzoeksvergaderingen presenteerde ik mijn assumpties waarom de interventie in de huisartsenpraktijken niet het effect sorteerde dat werd verwacht. Naar mijn idee vormde 'onderzoek' een te rigide kader voor de interventie en dat maakte dat in de huisartsenpraktijken de interventie niet zoals bedacht kon worden uitgevoerd. De onderzoeksopzet van experiment- en controlegroepen, alsook een uniforme behandeling van patiënten bleek in de huisartsenpraktijk van alledag niet mogelijk. Men was daar niet gewend om mensen naar wel of geen behandeling in te delen, álle patiënten dienden behandeld te worden. Omdat patiënten niet universeel, maar uniek zijn, dienen behandelingen op individuele patiënten afgestemd te worden. Bij de uitvoering werden dus allerhande aanpassingen gedaan om de interventie in de dagelijkse gang van zaken van de huisartsenpraktijken te laten passen. Het feit dat ik een relatie legde tussen 'het rigide karakter van onderzoek' en 'uitvoering van de interventie in de praktijken' maakte dat mijn collegaonderzoekers zich bewust gingen realiseren dat ook zij object van mijn etnografisch onderzoek waren geweest en nog steeds waren. Het maakte mijn positie binnen het project als een volwaardig lid van het onderzoeksteam problematisch; het positioneerde me als een externe observator.

De relatie met mijn collega-onderzoekers, die ik weloverwogen had opgebouwd en waarin ik keuzes bewust had afgewogen, was omgeslagen in een duidelijke scheiding tussen 'zij' en 'ik'. Het ging niet over een 'mixed methods-onderzoek' ten behoeve van het project, maar over 'hun' effectstudie en 'mijn' etnografisch onderzoek. Zoals een van mijn collega-onderzoekers het destijds verwoordde: 'iedereen is natuurlijk alleen maar bezig met zijn eigen ding' (fieldnote).

Was ik te vrij geweest in het presenteren van mijn observatieresultaten? Was ik dan toch niet genoeg bedacht geweest op de verschillen in focus van onze onderzoeken binnen het project? Had ik dan toch niet genoeg duidelijk kunnen maken dat ik ook hen observeerde? Had ik dan toch te weinig distantie bewaard en was ik te betrokken geraakt bij het gehele project, zodat ik niet meer kon beoordelen welke gevoeligheden mijn presentaties raakten in de effectstudie? Ik had er gedurende het project geen geheim van gemaakt dat ik ook 'onderzoek' observeerde, maar deze ontwikkeling maakte het wel moeilijk de 'toegang tot het veld' te behouden. Hoewel de keuze voor een 'mixed methods-onderzoek' vaak wordt ingegeven door argumenten over de hogere betrouwbaarheid en validiteit van gecombineerd onderzoek (zie bijvoorbeeld Creswell, Fetlers et al. 2004), bleek dat in dit project juist een belemmering. Het feit dat ik in mijn etnografisch onderzoek niet alleen keek naar de 'uitvoering van de interventie in de praktijken' en dat ik wat betreft die uitvoering ook nog een relatie durfde te leggen met 'het rigide 
karakter van onderzoek', maakte dat mijn collega's zich beoordeeld voelden in hun handelen en onderzoeksvaardigheden. Ik was te dichtbij gekomen; ik zorgde er niet voor dat de betrouwbaarheid van het gehele project verbeterde, maar stelde volgens mijn collega's juist hun 'onderzoekswaardigheid' ter discussie. Een van mijn collega-onderzoekers verwoordde het als volgt: 'je hebt er nooit een geheim van gemaakt dat je ons ook observeerde, maar een onderzoeker is nu eenmaal niet graag het object van onderzoek' (fieldnote). Met andere woorden, door mijn betrokkenheid bij het gehele project verloor ik het vertrouwen en ook de toegang tot mijn collega's.

\section{Een etnografische evenwichtsproef}

Hoewel ik verwachtte dat het uitvoeren van een etnografisch onderzoek onder collegaonderzoekers een 'makkelijke toegang tot het veld' zou kennen, doemden later juist problemen op. Het bleek een voortdurende evenwichtsproef, waarbij ik me als etnograaf voortdurend bewoog op de dunne scheidslijn tussen betrokkenheid en distantie en tussen toegang en geen toegang tot het onderzoeksveld. Betrokkenheid of distantie is niet een statische toestand, het is juist dynamisch en variabel. Zoals Zuiderent heel mooi laat zien, zijn betrokkenheid en distantie afhankelijk van de situatie die zich voordoet en waar je als onderzoeker naar moet handelen. Ze zijn afhankelijk van de rol (of rollen) die je zelf als etnograaf aanneemt of die je in je onderzoeksveld krijgt toegeschreven. Met andere woorden: afstand is 'gesitueerd'. Ongetwijfeld heeft deze evenwichtsproef de kwaliteit van mijn materiaal beïnvloed. Het is alleen moeilijk te zeggen hoe precies, want het toeval wil dat in dezelfde periode van de bemoeilijkte toegang, de effectstudie haar einde naderde en werd afgerond. Hiermee stopte ook de combinatie van onderzoeken. Ieder ging zijns weegs: volledige distantie.

Achteraf bezien, heb ik me wellicht toch niet goed genoeg gerealiseerd wat mijn etnografisch onderzoek voor mijn collega-onderzoekers betekende. Toch kan ik niet zeggen dat deze onderneming op een fiasco is uitgelopen. Mijn collega-onderzoeker is gepromoveerd op de effectstudie en ik hoop nog dit jaar te promoveren op het etnografisch onderzoek. Voor mij heeft dit project de bevindingen uit het wetenschap- en techniekonderzoek nog maar weer eens bevestigd. Zoals een technologie niet per definitie bepaalt hoe deze wordt toegepast of gebruikt en in de wisselwerking tussen technologie, onderzoek en samenleving haar vorm krijgt, zo is etnografisch onderzoek ook een pragmatisch proces dat gaandeweg een onderzoeksproject haar vorm krijgt en waarin je als onderzoeker moet anticiperen op wat er gebeurt.

\section{Literatuur}

Creswell, J.W., Fetters, M.D. et al. (2004). Designing a mixed methods study in primary care. Annals of Family Medicine, 2(1), 7-12.

Hackett, E.J., Amsterdamska, O. et al. (2008). The handbook of science and technology studies. Cambridge, MA: The MIT Press.

Zuiderent, T. (2002). Blurring the center; on the politics of ethnography. Scandinavian Journal of Information Systems, 14(2), 59-78. 